\title{
HUBUNGAN KECERDASAN SPASIAL-VISUAL DAN PRESTASI BELAJAR PADA MATERI BENTUK MOLEKUL
}

\author{
Ah. Fathul Jadid Anshori ${ }^{1}$, Rendy Priyasmika ${ }^{2}$, Kriesna Kharisma Purwanto ${ }^{3}$ \\ ${ }^{1,2,3}$ Pendidikan Kimia, Fakultas Keguruan dan Ilmu Pendidikan, Universitas Billfath
}

\section{INFO ARTIKEL}

Diterima : 17-7-2021

Disetujui : 3-9-2021
Kata Kunci:

Kecerdasan, spasialvisual, prestasi belajar, bentuk molekul

\begin{abstract}
Abstrak: Ilmu kimia terbagi menjadi dua konsep, yaitu konsep konkret dan terdefiinisi. Bentuk molekul merupakan salah satu konsep terdefinisi karena gagasannya berada pada tingkat molekuler dan tidak kasat mata. Sehingga, untuk memahami materi bentuk molekul dibutuhkan kecerdasan spasial-visual. Oleh sebab itu untuk mengetahui hubungan kecerdasan spasial-visual dan prestasi belajar pada materi bentuk molekul dilakukan dalam penelitian ini. Tujuan penelitian ini adalah untuk mengetahui ada atau tidaknya korelasi antara kecerdasan spasial-visual dengan prestasi belajar siswa kelas X IPA MA Hidayatul Ummah Pringgoboyo pada materi bentuk molekul. Penelitian ini menggunakan metode statistik inferensial dengan menggunakan statistik korelasi regresi untuk mengetahui ada atau tidaknya korelasi antara kecerdasan spasial-visual dengan prestasi belajar. Hasil penelitian ini menunjukkan tidak terdapat korelasi antara kecerdasan spasial-visual dengan prestasi belajar, hal ini dimungkinkan karena tidak hanya kecerdasan spasial-visual yang berperan dalam meningkatkan prestasi belajar.
\end{abstract}

\begin{abstract}
Chemistry is divided into two concepts, namely concrete and defined concepts. The shape of a molecule is one of the most defined concepts because the idea is at the molecular level and is not visible to the naked eye. So, to understand the material of molecular shape, spatial-visual intelligence is needed. Therefore, to find out the relationship between visual-spatial intelligence and learning achievement in molecular shape material, this study was carried out. The purpose of this study was to determine whether or not there was a correlation between spatial-visual intelligence and the learning achievement of class X IPA MA Hidayatul Ummah Pringgoboyo students on the material of molecular form. This study uses inferential statistical methods using regression correlation statistics to determine whether or not there is a correlation between visual-spatial intelligence and learning achievement. The results of this study indicate that there is no correlation between spatial-visual intelligence and learning achievement, this is possible because it is not only spatial-visual intelligence that plays a role in improving learning achievement
\end{abstract}

$\begin{array}{ll}\text { Nama } & \text { : Ah. Fathul Jadid Anshori }{ }^{1} \text {, Rendy Priyasmika }{ }^{2}, \text { Kriesna Kharisma Purwanto } \\ \text { Instansi } & : \text { Prodi Pendidikan Kimia FKIP Universitas Billfath } \\ \text { Alamat instansi } & : \text { Komplek PP. Al Fattah Siman Sekaran Lamongan Jawa Timur } \\ \text { Surel } & : \text { jadid.anshori@gmail.com }{ }^{1} \text {, rendy.priyasmika@ gmail.com }{ }^{2} \text {, vegaku87@ gmail.com }{ }^{3}\end{array}$

Ilmu kimia berasal dari bahasa Arab yaitu al-kimia yang berarti perubahan materi, oleh ilmuwan Arab Jabir bin Hayyan (700-778 M). Dari kata "al-kimia” dapat disimpulkan bahwa ilmu kimia berarti ilmu yang mempelajari rekayasa materi yaitu mengubah materi menjadi materi lain (Ridlo, 2019:1). Ilmu kimia merupakan ilmu yang diperoleh dan dikembangkan berdasarkan eksperimen yang mencari jawaban atas pertanyaan apa, mengapa, dan bagaimana gejala-gejala alam, khususnya yang berkaitan dengan komposisi, struktur dan sifat, transformasi, dinamika dan energitika zat. Oleh sebab itu, mata pelajaran kimia di SMA mempelajari segala sesuatu tentang zat 
KARANGAN: Jurnal Kependidikan, Pembelajaran, dan Pengembangan, Vol 03, No 02, Bulan September Tahun 2021, Hal 102-107

yang meliputi komposisi, struktur dan sifat, transformasi, dinamika dan energitika zat yang melibatkan keterampilan, dan penalaran. Ilmu kimia merupakan produk (pengetahuan kimia yang berupa fakta, teori, prinsip, dan hukum) temuan sintesis dan proses (Mustofa, 2011:1).

Konsep dalam ilmu kimia secara garis besar dibagi dalam 2 (dua) kategori, yaitu konsep konkret dan konsep terdefinisi. Konsep konkret digeneralisasi dari pengamatan langsung terhadap gejala-gejala alam atau eksperimen, misalnya konsep tentang zat padat dan zat cair. Selanjutnya konsep terdefinisi adalah gagasan yang berada pada tingkat molekuler yang dibangun dari gagasangagasan lebih mendasar. Konsep terdefinisi tidak dapat terbentuk langsung dari pengamatan karena keadaan sebenarnya tidak dapat diamati secara kasat mata (Harle, 2010:1). Agar dapat memahami konsep terdefinisi dengan baik, maka siswa memerlukan proses intelektual yang lebih kompleks dari pemahaman konsep konkret (Diniwati, 2011:1).

Menurut Carter dalam Woldeamanuel (2014:2), selain mempelajari konsep di kelas, pembelajaran kimia juga membutuhkan aktivitas lain berupa praktikum di laboratorium. Praktikum penting dilakukan karena akan memberikan pemahaman secara mendalam kepada siswa dan memberikan gambaran secara nyata tentang materi yang diajarkan. Namun kenyataannya masih ada guru yang tidak mengajak siswa untuk melakukan praktikum, hal ini karena guru belum memaksimalkan kompetensinya dan fasilitas laboratorium yang ada di sekolah kurang memadai.

Uraian fakta di atas pada akhirnya menyebabkan siswa kurang memahami konsep materi kimia secara utuh dan berdampak pada hasil belajar siswa yang rendah. Menurut Mustofa (2011:1) kesulitan belajar siswa disebabkan oleh beberapa faktor, yaitu (a) Siswa tidak memahami konsep, (b) Kurang terampil dalam mengerjakan soal, (c) Siswa tidak dapat menerapkan konsep dalam menyelesaikan soal, dan (d) Siswa kurang cermat dalam penggunaan konsep. Selanjutnya Sunyono dalam Mustofa (2011:1) mengemukakan bahwa kesulitan dalam memahami konsep-konsep kimia disebabkan karena menyangkut reaksi-reaksi kimia dan hitungan-hitungan. Selain itu juga menyangkut konsep-konsep yang bersifat abstrak dan dianggap oleh siswa merupakan materi yang relatif baru dan belum pernah diperoleh ketika di Sekolah Menengah Pertama. Kesulitan dalam memahami satu konsep kimia akan menyebabkan kesulitan memahami konsep yang lain karena ilmu kimia bersifat kompleks dan konsepnya saling berkaitan satu sama lain.

Salah satu pokok bahasan dalam kimia adalah ikatan kimia yang diajarkan di kelas X dan diperdalam kembali di kelas XI. Pada materi ikatan kimia mempelajari beberapa sub materi, diantaranya ikatan kovalen, ikatan ionik, bentuk molekul, dan kepolaran molekul. Untuk mempelajari bentuk molekul siswa dituntut untuk dapat menerapkan teori pasangan elektron kulit valensi (VSEPR) dan teori domain elektron. Keberhasilan siswa dalam menggambarkan bentuk molekul sangat dipengaruhi oleh pemahaman siswa pada teori yang membantu siswa dalam menggambarkan bentuk molekul dalam hal ini adalah teori domain elektron. Namun, banyak siswa yang mengalami kesulitan menggambarkan bentuk molekul karena tidak dapat diamati secara langsung menggunakan indera pengelihatan, sehingga siswa tidak mampu memproyeksikan gambaran molekul dalam pikirannya (Cardellini, 2012:1).

Kesulitan dalam mempelajari materi bentuk molekul tersebut diduga juga dialami oleh siswa kelas X IPA MA Hidayatul Ummah Priggoboyo. Berdasarkan hasil wawancara dengan guru mata pelajaran kimia dan pemberian kuesioner kepada siswa diperoleh informasi bahwa siswa mengalami kesulitan dalam menggambarkan bentuk molekul. Selain itu dari hasil wawancara juga diperoleh informasi bahwa metode yang digunakan guru selama ini untuk mengajar model molekul hanya strategi pembelajaran konvensional atau ceramah dan strategi pembelajaran langsung. Strategi pembelajaran langsung memang membuat siswa terampil untuk berdiskusi, namun di sisi lain strategi ini juga membuat siswa pemahamannya berbeda, karena akan ada satu dua siswa yang mendominasi. Strategi ceramah memang tidak menyita banyak waktu dibandingkan dengan strategi pembelajaran langsung, namun strategi ini dapat menyebabkan siswa menjadi bosan dan pembelajaran hanya berpusat pada guru. Anggriani dalam Raguwan (2014:2). Kesulitan ini selain 
KARANGAN: Jurnal Kependidikan, Pembelajaran, dan Pengembangan, Vol 03, No 02, Bulan September Tahun 2021, Hal 102-107

seperti yang sudah dijelaskan sebelumnya juga dimungkinkan berkaitan dengan kecerdasan spasialvisual siswa yang rendah.

Marhayati dalam Apecawati (2014:1) menjelaskan bahwa kecerdasan spasial-visual adalah kecerdasan yang berkaitan dengan persepsi visual (mata) maupun pikiran serta kemampuan mentransformasikan persepsi visual spasial seperti yang dilakukan dalam kegiatan melukis, mendesain pola ataupun merancanag bangunan. Menurut Agustin dalam Apecawati (2014:1-2), kemampuan yang ditunjukkan seseorang yang tinggi dalam kecerdasan ini adalah menggambar yang terkadang mendekati persis, seseorang pun sudah mampu menceritakan gambar yang sifatnya visual dan juga telah mampu membuat konstruksi 3 (tiga) dimensi serta tampak lebih mudah belajar dengan menngunakan teks dan gambar. Selain itu penalaran spasial sangat penting untuk penalaran tentang hubungan dalam 3 (tiga) dimensi dan mewakili informasi dalam diagram (Wu, 2004:2).

\section{METODE PENELITIAN}

Penelitian ini merupakan penelitian kuantitatif inferensial dengan menggunakan rancangan penelitian one shoot case study. Penelitian kuantitatif inferensial digunakan untuk mengetahui hubungan (korelasi) antara kecerdasan spasial-visual dengan prestasi belajar pada materi bentuk molekul. Rancangan penelitian one shoot case study dipilih karena hanya melibatkan satu kelas sebagai sampel penelitian. Teknik pengumpulan data yang digunakan dalam penelitian ini adalah dengan memberikan tes figural berjumlah 12 soal yang dikembangkan oleh Fathoni (2013) untuk mengetahui tingkat kecerdasan spasial-visual siswa dan dan tes kognitif materi bentuk molekul berjumlah 10 soal pilihan ganda dan 5 soal uraian yang sebeumnya telah divalidasi isi dan butir soal. Tes figural diberikan sebelum dan sesudah diajarkan menggunakan strategi kooperatif TGT-Puzzle, sedangkan tes kognitif materi bentuk molekul hanya diberikan setelah diajarkan dengan strategi kooperatif TGT-Puzzle. Analisis data dilakukan dengan teknik analisis statistik inferensial menggunakan uji korelasi regresi menggunakan bantuan SPSS 21.0 yang digunakan untuk menguji korelasi antara kecerdasan spasial-visual dengan prestasi belajar

\section{HASIL PENELITIAN}

Berdasarkan hasil tes figural untuk mengetahui tingkat kecerdasan spasial-visual disajikan dalam Tabel 1.

Tabel 1 Hasil Uji Tes Figural

\begin{tabular}{|c|c|c|c|c|c|}
\hline \multirow{2}{*}{ Siswa } & \multicolumn{4}{|c|}{ Tes Spasial-Visual } & \multirow{2}{*}{$\begin{array}{c}\text { Jumlah } \\
\text { Siswa }\end{array}$} \\
\hline & Pretest & Kriteria & Posttest & Kriteria & \\
\hline A & 55 & \multirow{5}{*}{$\begin{array}{c}\text { High } \\
\text { Average }\end{array}$} & 70 & \multirow{5}{*}{ Superior } & \multirow{5}{*}{5} \\
\hline $\mathrm{E}$ & 50 & & 75 & & \\
\hline $\mathrm{F}$ & 60 & & 75 & & \\
\hline G & 50 & & 70 & & \\
\hline $\mathrm{O}$ & 55 & & 75 & & \\
\hline $\mathrm{N}$ & 45 & \multirow{2}{*}{$\begin{array}{c}\text { High } \\
\text { Average }\end{array}$} & 60 & \multirow[t]{2}{*}{ High Average } & \multirow{2}{*}{2} \\
\hline Q & 50 & & 65 & & \\
\hline B & 35 & \multirow{6}{*}{ Average } & 40 & \multirow{6}{*}{ High Average } & \multirow{6}{*}{8} \\
\hline $\mathrm{C}$ & 35 & & 45 & & \\
\hline $\mathrm{D}$ & 35 & & 50 & & \\
\hline I & 30 & & 40 & & \\
\hline $\mathbf{J}$ & 30 & & 40 & & \\
\hline $\mathrm{K}$ & 20 & & 45 & & \\
\hline
\end{tabular}


KARANGAN: Jurnal Kependidikan, Pembelajaran, dan Pengembangan, Vol 03, No 02, Bulan September Tahun 2021, Hal 102-107

\begin{tabular}{|c|c|c|c|c|c|}
\hline \multirow{2}{*}{ Siswa } & \multicolumn{4}{|c|}{ Tes Spasial-Visual } & \multirow{2}{*}{$\begin{array}{c}\text { Jumlah } \\
\text { Siswa }\end{array}$} \\
\hline & Pretest & Kriteria & Posttest & Kriteria & \\
\hline M & 20 & & 40 & & \\
\hline $\mathrm{R}$ & 35 & & 65 & & \\
\hline $\mathrm{P}$ & 0 & & 20 & & \\
\hline $\mathrm{H}$ & 25 & Average & 35 & Average & 3 \\
\hline $\mathrm{L}$ & 0 & & 30 & & \\
\hline Rata-rata & 35,00 & Average & 52,22 & igh Avera & \\
\hline
\end{tabular}

Berdasarkan Tabel 1 diketahui bahwa tingkat kecerdasan spasial-visual awal siswa termasuk dalam kategori Average, sedangkan setelah dibelajarkan menggunakan strategi kooperatif TGTPuzzle, tingkat kecerdasan spasial-visual siswa bergeser masuk dalam kategori High Average Berdasarkan hasil tes materi bentuk molekul untuk mengetahui tingkat prestasi belajar siswa diperoleh data skor yang disajikan dalam Tabel 2.

Tabel 2 Hasil Uji Tes Materi Bentuk Molekul

\begin{tabular}{ccccc}
\hline \multirow{2}{*}{ Siswa } & \multicolumn{2}{c}{ Skor Siswa } & \multirow{2}{*}{ Kriteria } & \multirow{2}{*}{ Jumlah Siswa } \\
\cline { 2 - 3 } & Pretest & Posttest & & \\
\hline A & 58 & 60 & & \\
\hline B & 58 & 60 & & \\
\hline C & 60 & 84 & & \\
\hline D & 64 & 84 & & \\
\hline E & 70 & 84 & & \\
\hline G & 65 & 80 & & \\
\hline H & 56 & 60 & & \\
\hline I & 58 & 80 & & \\
\hline K & 55 & 84 & & \\
\hline L & 50 & 56 & & \\
\hline M & 58 & 60 & & \\
\hline O & 68 & 84 & & \\
\hline P & 55 & 80 & & \\
\hline Q & 60 & 64 & & \\
\hline R & 60 & 64 & & \\
\hline J & 64 & 64 & Tetap & \\
\hline F & 85 & 84 & Menurun & \\
\hline N & 62 & 60 & $\mathbf{7 1 , 7}$
\end{tabular}

Berdasarkan Tabel 2 dapat diketahui bahwa 83\% siswa kelas X IPA MA Hidayatul Ummah mengalami peningkatan nilai, sementara 5,5\% siswa tidak mengalami perubahan nilai, dan $11,5 \%$ siswa mengalami penurunan nilai prestasi belajar pada materi bentuk molekul.

Berdasarkan uji korelasi regresi dengan bantuan SPSS 21.0 diperoleh hasil sebagai berikut. 
KARANGAN: Jurnal Kependidikan, Pembelajaran, dan Pengembangan, Vol 03, No 02, Bulan September Tahun 2021, Hal 102-107

Tabel 3 Hasil Uji Korelasi Antara Kecerdasan Spasial-Visual dengan Prestasi Belajar

\begin{tabular}{cccc}
\hline Tes & Nilai $\mathbf{r}_{\text {tabel }}$ & Koefisien Korelasi $\left(\mathbf{r}_{\text {hitung }}\right)$ & Signifikansi (Sig.) \\
\hline Pretest & 0,4683 & 0,729 & 0,001 \\
\hline Posttest & 0,4683 & 0,247 & 0,323 \\
\hline
\end{tabular}

Berdasarkan data hasil analisis korelasi terdapat korelasi pada pretest, sementara pada posttest tidak terdapat korelasi antara prestasi belajar dan kecerdasan spasial-visual. Hal ini dimungkinkan disebabkan pembelajaran yang kurang efektif, karena hanya berlangsung selama 3 (tiga) kali pertemuan. Selain itu juga dimungkinkan karena bukan hanya kecerdasan spasial-visual saja yang berperan dalam meningkatkan prestasi belajar siswa, melainkan terdapat faktor lain yang dapat mempengaruhi prestasi belajar seperti gaya belajar, faktor psikologis, bahkan kondisi lingkungan yang tidak mendukung prestasi belajar.

Hal ini sejalan dengan penelitian Syafi'i (2018:9) yang menyatakan bahwa prestasi belajar dipengaruhi oleh 2 (dua) faktor, yaitu (1) faktor internal, seperti psikologis, gaya belajar, dan kematangan mental, dan (2) faktor eksternal, seperti kondisi sekolah, kondisi lingkungan, dan kondisi keluarga. Kemudian Chandran (1987) menyatakan bahwa kemampuan penalaran formal dan pengetahuan pada materi sebelumnya dapat mempengaruhi prestasi kognitif siswa pada mata pelajaran kimia. Selain itu, penelitian Nath (2012:60) menyatakan bahwa latar belakang ekonomi juga dapat mempengaruhi prestasi belajar siswa.

\section{SIMPULAN DAN SARAN Simpulan}

Berdasarkan hasil analisis data, maka dapat disimpulkan terdapat korelasi pada pretest, sementara pada posttest tidak terdapat korelasi antara kecerdasan spasial-visual dan prestasi belajar siswa kelas X IPA MA Hidayatul Ummah Pringgoboyo pada materi bentuk molekul. Hal ini dimungkinkan disebabkan pembelajaran yang kurang efektif, karena hanya berlangsung selama 3 (tiga) kali pertemuan. Selain itu juga dimungkinkan karena bukan hanya kecerdasan spasial-visual saja yang berperan dalam meningkatkan prestasi belajar siswa, melainkan terdapat faktor lain yang dapat mempengaruhi prestasi belajar seperti gaya belajar, faktor psikologis, bahkan kondisi lingkungan yang tidak mendukung prestasi belajar

\section{Saran}

Saran yang dapat peneliti sampaikan untuk penelitian serupa adalah hendaknya mempersiapkan waktu dengan seefisien mungkin, karena penelitian ini memiliki banyak tahap yang tidak bisa dipisahkan satu sama lain

\section{DAFTAR RUJUKAN}

Apecawati, Linda Dwi. Sahputra, Rachmat \& Lukman Hadi. 2018. Hubungan Kecerdasan VisualSpasial dengan Kemampuan Menggambarkan Bentuk Molekul pada Mahasiswa. Jurnal Pendidikan dan Pembelajaran Khtulistiwa. $7(1)$ : 1-11. https://jurnal.untan.ac.id/index.php/jpdpb/article/view/23788

Cardellini, L. 2012. Chemistry: Why the Subject Is Difficult?. Educacion Quimica. 23(2): 305-310. http://www.scielo.org.mx/scielo.php?pid=S0187

Chandran, Sarath. Treagust, David F., Tobin, Kenneth. 1987. The Role of Cognitive Factors In Chemistry Achievement. Journal of Research In Science Teaching. 24(2): 145-160. https://doi.org/10.1002/tea.3660240207

Diniwati, A. (2011). Hubungan Antara Kemampuan Berpikir Formal Dengan Kemampuan Memberikan Gambaran Mikroskopis Konsep Asam Basa pada Siswa Kelas XI SMA Negeri 1 Gorontalo. Skripsi. Jurusan Pendidikan Kimia FMIPA Universitas Negeri Gorontalo. 
KARANGAN: Jurnal Kependidikan, Pembelajaran, dan Pengembangan, Vol 03, No 02, Bulan September Tahun 2021, Hal 102-107

Fathoni, Luqman. 2013. Profil Kecerdasan Visual-Spasial Siswa dalam Memahami Gambar Bangun Ruang yang Tersusun Dari Beberapa Bangun Kubus. Gamatika. 3(2): 155-161. http://journal.unipdu.ac.id/index.php/gamatika

Harle, Marissa \& Towns, Marcy. 2010. A Review of Spatial Ability Literature, Its Connection to Chemsistry, and Implications for Instruction. American Chemical Society and Division of Chemical Education. 20(20): A-J. https://doi.org/10.1021/ed900003n

Mustofa. Pikoli, Masrid \& Suleman, Nita. 2011. Hubungan Antara Kemampuan Berpikir Formal dan Kcerdasan Visual-Spasial dengan Kemampuan Menggambarkan Bentuk Molekul Siswa Kelas XI MAN Gorontalo Tahun Ajaran 2010/2011. Jurnal Entropi. 8(1): 551-561. http://ejurnal.ung.ac.id/index.php/JE/article/view/1164

Nath, Samir Ranjan. 2012. Factors Influencing Primary Students' Learning Achievement in Bangladesh. Research in Education. 88(1): 50-63. https://doi.org/10.7227\%2FRIE.88.1.5

Raguwan, Siang Tandi Gonggo \& Sabang, Sri Mulyani. 2014. Pengaruh Model Pembelajaran Kooperatif Tipe Snowball Throwing Terhadap Hasil Belajar Siswa Pada Materi Bentuk Molekul Kelas XI IPA SMA Negeri 1 Pasangkayu. Jurnal Akademika Kimia. 3(1): 1-7.

Ridlo, Muhammad Fahmi \& Novita, Dian. 2019. Penerapan Model Pembelajaran Process Oriented Guided Inquiry Learning (POGIL) untuk Melatihkan Multiple Intelegences Siswa pada Materi Ikatan Kimia Kelas X MAN Surabaya. Unesa Journal Of Chemical Education. 8(3): 282-287. https://jurnalmahasiswa.unesa.ac.id/index.php/journal-of-chemicaleducation/article/view/30551

Syafi'i, Ahmad. Marfiyanto, Tri \& Rodiyah, Siti Kholidatur. 2018. Studi Tentang Prestasi Belajar Siswa dalam Berbagai Aspek dan Faktor yang Mempengaruhi. Jurnal Komunikasi Pendidikan. 2(2): 115-123. https://doi.org/10.32585/jkp.v2i2.114

Woldeamanuel, Melaku Masresha. Atagana, Harrison \& Engida, Temechegn. 2014. What Makes $\begin{array}{llll}\text { Chemistry } & \text { Difficult?. } & \text { AJCE. } & \text { 31-43. }\end{array}$ https://www.ajol.info/index.php/ajce/article/view/104070

Wu, Hsin-kai \& Shah, Priti. 2004. Exploring Visuospatial Thinking in Chemistry Learning. Wiley Online Library. 88(3): 465-492. https://doi.org/10.1002/sce.10126 